\title{
Homeobox Protein Hox-B9
}

National Cancer Institute

\section{Source}

National Cancer Institute. Homeobox Protein Hox-B9. NCI Thesaurus. Code C101592.

Homeobox protein Hox-B9 (250 aa, $28 \mathrm{kDa}$ ) is encoded by the human HOXB9 gene.

This protein is involved in transcriptional regulation during embryonic development. 